\title{
Modelling Approach of an Innovation Process in Engineering Education: The Case of Mechanical Engineering
}

\author{
Imane Zergout ${ }^{1}$, Souad Ajana ${ }^{1}$, Catherine Adam $^{2} \&$ Soumia Bakkali ${ }^{1}$ \\ ${ }^{1}$ Laboratory of Engineering Research (LRI), Higher National School of Electricity and Mechanics (ENSEM), \\ University of Hassan II, Casablanca, Morocco \\ ${ }^{2}$ Training Research Centre (EA 1410 CNAM Paris), Higher National School of Advanced techniques (ENSTA) \\ Bretagne, Brest, France \\ Correspondence: Imane Zergout. Laboratory of Engineering Research (LRI), Higher National School of Electricity \\ and Mechanics (ENSEM), University of Hassan II, El Jadida Road, km 7, 8118, Oasis, Casablanca, Morocco.
}

Received: November 23, 2019

Accepted: December 20, 2019 Online Published: December 27, 2019

doi:10.5430/ijhe.v9n2p25

URL: https://doi.org/10.5430/ijhe.v9n2p25

\begin{abstract}
Nowadays, the concept of innovation is omnipresent in most political discourses as well as in technological, socio-economic and scientific development plans. Innovation is essential for solving complex problems in new ways, which can lead countries to development and prosperity. The realisation of an innovation is not the result of a random act, but the product of a multidisciplinary process, rich in methods and scientific and technical tools, using materials and human resources. These human resources, in particular engineers, must possess both technical and soft skills that strengthen their capacity to innovate, and which have been in continual development since the initial training phase. Innovation is at the heart of engineer training concerns and requires management and structuring according to a well-defined process.

The objective of this paper is to present the approach followed to define an innovation training process model for engineers through Project Based Learning (PBL). In this work, we have identified the main components of our process through a combination of data from the literature review and the results of an empirical study. Innovative projects in the field of mechanical engineering, carried out by future Moroccan engineers, were studied in depth. The results of the study enabled the identification of the different elements characterising the process of carrying out an innovative project such as the inputs, outputs, control milestones and resources required for the implementation of innovative educational projects in this field. These elements were supported by semi-directive interviews to form the basis of our systemic modelling.
\end{abstract}

Keywords: innovation, process, training, mechanical engineering, modelling, PBL

\section{Introduction}

Innovation is a driving force for the socio-economic development of countries in general, and Morocco is no exception in the sense that it has oriented its concerns towards a knowledge-based policy and innovation (Association Marocaine des investisseurs en capital (AMIC), 2014). The need within these economies for highly qualified engineers capable of successfully carrying out innovative projects is increasing. Indeed, production and innovations in industrial companies are largely based on the skills and innovative capacities of engineers (Kövesi \& Csizmadia, 2018). Although experience plays an important role in the process of acquiring these skills, engineer education remains a fundamental support for their building.

The ability to innovate is based on a set of skills and knowledge that generates creative thinking among engineers and future engineers and triggers the action of producing something new in the field of their expertise. These skills are not merely technical; they also include soft skills, which are crucial in boosting innovation. Soft skills can include autonomy, proactivity, accountability, communication, problem-solving, etc. (Besançon, Lubart, \& Barbot, 2013) (Ferguson, Jablokow, Ohland, \& Purzer, 2017). They are encouraged through active pedagogical methods such as digital integration, openness to the international arena, learning through individual, and collective projects, etc. (Gil, Gardelle, \& Tabas, 2018). In this work we especially focus on project based learning (PBL) activities that involve a set of actors in real situations (Bourgeois-Bougrine, Buisine, Vandendriessche, Glaveanu, \& Lubart, 2017). This allows future engineers to follow the different technical and analytical steps involved in solving complex 
problems in socio-technical contexts, and to reflect deeply by taking into consideration all the characteristics and issues of the project's scope (be they social, cultural, economic, political, and technological...) (Adam \& Coco, 2018).

The objective of this work is to propose an innovative project implementation process model that could be integrated as a project module into the training of mechanical engineers in an engineering school in Morocco. Our modelling approach is based on a triangulation approach, combining a set of data from the literature review, in-depth studies of innovative projects, and interviews with industrialists. Through adopting a process approach combining logic and interactivity, the authors aim to model the innovation process in order to structure the skills, knowledge and resources required. The first step of this research work is devoted to describing the context, objectives and methodology of the empirical study conducted. Then, we analyse the data collected from case studies carried out in Moroccan engineering schools, and interviews with industrialists. The objective is to give a detailed definition of the components of our model. We conclude with some feedback and perspectives from the study.

\section{State of the Art}

This paper proposes to study the phenomenon of innovation in the context of engineering education. We adopt a particular approach, which is based on the combination of innovation engineering methods applied in industry and pedagogical engineering methods. Thus, we propose to model the process that engineering students employ to carry out innovation projects. We consider this process in itself as a learning process that allows engineering students to acquire the skills necessary to achieve innovations through a real experience of innovation and creativity. According to Fernez-Walch and Romon (2013), the innovation process is perceived as a learning process that promotes spaces for the creation of knowledge and skills and interactions between actors, which makes it possible to produce not only innovations (products, services, etc.), but also diverse resources that lead to the derivation of the basic project into new innovation projects.

\subsection{Project-Based-Learning Activities}

Project pedagogy is one of the active pedagogies that allow students to master certain key skills that help develop critical thinking and creative potential and boost their ability to innovate (Soares, Sepúlveda, Monteiro, Lima, \& Dinis-Carvalho, 2012). It represents an effective strategy to increase student participation in their learning environment, encourage and develop the spirit of creativity, discover new concepts and experiences and the frequent use of technological and digital tools (Gómez-Pablos, Del Pozo, \& Muñoz-Repiso, 2017).Several studies have described and analysed their feedback on the role played by students in carrying out projects fostering their spirit of innovation and creativity. Table 1 summarises some of the work that is related to our theme of innovation training through the project-based approach. 
Table 1. Some studies examining the issue of the use of PBL to foster innovation in engineering education.

\begin{tabular}{|c|c|c|c|}
\hline Authors & Aims of the study & Methods & Main Results \\
\hline $\begin{array}{l}\text { Silva,Leite,Vilas-Boas } \\
\text { and Simoes (2019) }\end{array}$ & $\begin{array}{c}\text { Contribution to the } \\
\text { stimulation of innovation } \\
\text { and entrepreneurship among } \\
\text { students through experience } \\
\text { in product design and } \\
\text { development in student } \\
\text { projects. }\end{array}$ & $\begin{array}{l}\text { Qualitative evaluation } \\
\text { and analysis of three } \\
\text { projects for the design } \\
\text { and development of } \\
\text { similar but independent } \\
\text { products within three } \\
\text { higher education } \\
\text { institutions with the } \\
\text { same characteristics } \\
\text { (accreditation, } \\
\text { curriculum, assignments, } \\
\text { etc.). }\end{array}$ & $\begin{array}{l}\text {-Impact of teaching students } \\
\text { from different backgrounds on } \\
\text { the development of new } \\
\text { products. } \\
\text {-The ideal educational } \\
\text { environment would be to have } \\
\text { all the expertise of each of the } \\
\text { three educational institutions in } \\
\text { these areas brought together in } \\
\text { the same educational group } \\
\text { project. }\end{array}$ \\
\hline $\begin{array}{c}\text { Bourgeois-Bougrine et } \\
\text { al. (2017) }\end{array}$ & $\begin{array}{l}\text { Proposal of a training model } \\
\text { for innovation and creativity } \\
\text { through projects. This } \\
\text { model is based on a } \\
\text { technical product design } \\
\text { approach. This approach is } \\
\text { based on a set of steps } \\
\text { ranging from the } \\
\text { identification of } \\
\text { requirements to the } \\
\text { construction of the } \\
\text { prototype of the creative } \\
\text { solution. }\end{array}$ & $\begin{array}{l}\text { Qualitative evaluation of } \\
\text { the effectiveness of } \\
\text { innovative design tools } \\
\text { during a product design } \\
\text { challenge carried out by } \\
\text { engineering students. }\end{array}$ & $\begin{array}{l}\text { Differences exist in individual } \\
\text { capacities in the design stages, } \\
\text { in the performance of the } \\
\text { innovation process, and in the } \\
\text { nature and effectiveness of the } \\
\text { tools used. The most creative } \\
\text { students used more creative } \\
\text { tools (such as analogy, } \\
\text { characters, mental mapping, } \\
\text { reverse brainstorming...etc.) }\end{array}$ \\
\hline $\begin{array}{l}\text { Buizine, Moulin and } \\
\text { Brandin (2015) }\end{array}$ & $\begin{array}{l}\text { The comparison of two } \\
\text { main types of innovation } \\
\text { processes: the positivist } \\
\text { process implemented in } \\
\text { large groups and industry } \\
\text { and the constructivist and } \\
\text { iterative process, the most } \\
\text { used in start-ups. }\end{array}$ & $\begin{array}{l}\text { Qualitative comparative } \\
\text { study of the two types of } \\
\text { processes, through their } \\
\text { implementation in two } \\
\text { pedagogical } \\
\text { experiments. The first } \\
\text { concerns individual } \\
\text { innovation projects and } \\
\text { the second concerns } \\
\text { group projects. }\end{array}$ & $\begin{array}{l}\text { Success and relevance of the } \\
\text { constructivist model, which is } \\
\text { based on a body of knowledge } \\
\text { and know-how such as: } \\
\text { analysis of users' needs, } \\
\text { mastery of creative approaches } \\
\text { and methods, mentoring, } \\
\text { collective work, etc. }\end{array}$ \\
\hline $\begin{array}{c}\text { Kojmane and } \\
\text { Aboutajeddine (2015) }\end{array}$ & $\begin{array}{l}\text { Proposal for a project to } \\
\text { design and develop } \\
\text { innovative and } \\
\text { multidisciplinary products } \\
\text { in order to improve the } \\
\text { ability of mechanical } \\
\text { engineering students to } \\
\text { solve problems and develop } \\
\text { innovative products. }\end{array}$ & $\begin{array}{l}\text {-Qualitative evaluation } \\
\text { of projects carried out by } \\
\text { engineering students. } \\
\text {-Analysis of the impact } \\
\text { of the use of technical } \\
\text { methods on the results, } \\
\text { as well as creative } \\
\text { methods to generate } \\
\text { solutions. }\end{array}$ & $\begin{array}{l}\text { Positive impact of technical } \\
\text { methods and the use of } \\
\text { information technologies (robot } \\
\text { linked to a Lego game, } \\
\text { simulation software...) in } \\
\text { promoting creativity and the } \\
\text { ability to produce innovations } \\
\text { among engineering students. }\end{array}$ \\
\hline
\end{tabular}

\subsection{The Innovation Process}

The review of the various works on innovation management has shown that the innovation process has undergone a major evolution. Recent work defines the innovation process from a systemic point of view as a complex and multidisciplinary process that takes the form of an intelligible entanglement of steps characterized by correlations and 
interactions between its components and between its stakeholders (Fernez-walch \& Romon, 2013) (Ferone, Pietroni, Petroccia, \& Alberto, 2018).

Despite the disparities between the different models proposed in the literature, they overlap in the representation of the process as a set of operational activities that add value to the input data. Several authors have proposed and tested systemic models based on different methods within industrial companies (systems engineering, process modelling using BPM and IDEF... etc.). We mention among others:

- Bernstein and Singh (2006) proposed an integrated model of the innovation process where the results of technological progress interfere with market demand to generate creative ideas. The main steps in this process are: idea generation, innovation support, innovation development, and innovation implementation.

- Christofol, Corsi, Crubleau, Delamarre, and Samier (2011) developed a model of the innovation process using a variety of multidisciplinary tools and methods. This model has been implemented in the automotive and mechanical industry. Its main steps are as follows: at the outset: ideas and strategic or technological marketing expectation steps: create the innovation portfolio, monitor and manage knowledge, create ideas, develop the product and its components, consolidate and enhance the product, test and evaluate, communicate to the market.

- Penide, Gourc, Pingaud, and Peillon (2013) proposed system modelling of the innovation process using business process modelling (BPM) methods. The model develops operational, support and management activities within this innovation process in parallel with the various business lines within the company. The main steps of the proposed implementation process are: define the problem, search for knowledge (data), transform existing knowledge to create a new form of innovation, exploit a new form of innovation in the form of innovations, register the intellectual property, or new knowledge rights.

\subsection{Synthesis}

The study of project pedagogy shows that the learning of the different skills and knowledge likely to provide the student with both the technical and non-technical skills necessary for innovation takes place through the student's involvement in real situations where he/she faces technical and scientific constraints. PBL helps to improve the quality of learning especially if it is assisted by ICTs or e-learning activities, through making students more interactive and autonomous (Widyaningsih \&Yusuf, 2020).

The objective of the literature review of innovation management is to determine the main phases of the innovation process. Although the titles of the different stages in the innovation process may differ from one model to another, the meaning and content of these stages are the same. Among the recurring steps in most models are: creativity, idea generation, development, realisation and diffusion.

Thus, our work is interdisciplinary because it covers both innovation pedagogy and innovation engineering. Our perspective is to take advantage of the relevance of the methods applied in industry to model the innovation process within engineering schools in order to stimulate innovation and creativity.

\section{Empirical Study}

\subsection{Context and Objectives}

Our study concerns mechanical engineer training in Morocco, and focuses in particular on strengthening innovation through the project-based learning approach. Mechanical engineering exists in 8 public engineering schools situated in different cities in Morocco (ENSEM, EMI, ENIM, ENSAM, ENSA...etc.). Most of the programs related to this training, contain courses in the design and development of mechanical systems, belonging to different fields ranging from everyday consumption, to automotive manufacturing, aeronautics, and machinery... etc. However, the course content is based on functional analysis, sizing, calculation of mechanical structures, and industrial design...etc. This training recommends rigour and that the students' work should conform to existing guides and standards, however, it does not include the approaches and tools required to generate creative and innovative ideas. This, in turn, results in a lack of innovation management courses integrated into mechanical engineering programmes.

Moreover, modules that include work on application projects prioritise the calculation and technical development of existing products. The implementation of innovative projects is most often developed through extracurricular activities and students' participation in national and international competitions. These activities encourage students to carry out projects that demonstrate creativity, inventiveness, and technical rigour.

However, in general, most solutions proposed by future engineers to solve problems related to their fields are often classic solutions and do not demonstrate creativity or innovation (Forest, Chouteau, \& Nguyen, 2011). This is the result of a lack of standardised and precise models of the organisation of means, resources, and methods used to 
boost the capacity of future engineers to innovate (Gil, Gardelle, \& Tabas, 2018). In an attempt to address these problems, we have conducted research aimed at understanding and improving the process of training engineers in innovation through projects.

\subsection{Methods}

\subsubsection{Case Study Method}

Our work is conducted as part of a qualitative study based on case studies. It is an empirical study of a complex and contemporary phenomenon within its context (Yin, 2003). This methodology allows us to understand the factors and events that characterise the context of a complex phenomenon through the collection of different types of data. We approached our field of study by interacting with actors in different functions based on observation techniques, interviews, and written data collection. In order to ensure the objectivity of the work, we decentralised facts through the triangulation of data from different sources and using different methods. We listened, noted, and recorded carefully everything that was said by the interviewees and examined the content of the documents in order to assimilate as much information and implicit and explicit messages as possible.

\subsubsection{Process Approach}

We consider that innovation training can be assimilated to a process because it involves a set of sequentially linked steps aimed at transforming engineering students into innovative actors, in order to satisfy the needs and requirements expressed by different organisations in the socio-economic world. Consequently, this approach, which is based on listening to the needs of the external environment and implementing measures to satisfy them, is similar to the quality approach, the aim of which is customer satisfaction.

The process approach consists of a methodical and detailed description of an organisation or activity generating added value in order to control and continuously improve it by acting on the interactions between the process and its environment (ISO 9001:2015, 2015).

The process approach divides the system studied into three main sub-processes that interact and exchange a flow of information and resources (Brandenburg \&Wojtyna, 2006). Table 2 below describes the characteristics of these sub-processes.

Table 2. Characteristics of the sub-processes constituting the overall process

\begin{tabular}{cc}
\hline Sub-process & Characteristics \\
\hline $\begin{array}{c}\text { Implementation } \\
\text { process }\end{array}$ & $\begin{array}{c}\text { A set of activities spread over time and implemented to transform inputs defined by } \\
\text { customer requirements, into outputs with added value to satisfy those requirements }\end{array}$ \\
$\begin{array}{c}\text { A set of activities whose function is to provide the different means (human resources, } \\
\text { methods, equipment, and financing) essential to the different sub-processes of the system. } \\
\begin{array}{c}\text { Management } \\
\text { process }\end{array}\end{array}$ & $\begin{array}{c}\text { A set of activities allowing the management and control of other processes in the system } \\
\text { by transforming information, the origin of which is internal or external to the system, into } \\
\text { directives. }\end{array}$ \\
\hline
\end{tabular}

\subsection{Description of the Study}

The empirical study we conducted includes multiple case studies aimed at collecting the varied and rich data needed to characterise and define our process.

It is composed of two main stages. First, we conducted semi-directive interviews with 15 industrial actors from companies located in Morocco. Some of the contacts belong to large groups (OCP Group, VINCI ENERGY, Jacobs Engineering, Oulmes Water, Altran, etc.), and others belong to the public sector such as the ministries of transport and industry. We interviewed an engineer and a human resources manager from each company.

The second phase of this work consists in an in-depth study of 25 innovative projects (both academic and extracurricular) carried out by mechanical engineering students from various Moroccan engineering schools. To do this, we selected a sample of innovative projects based on the criteria proposed by the Moroccan Office of Industrial and Commercial Property (OMPIC). It is a Moroccan organisation that is in charge of granting patents (OMPIC, 2014). These criteria are novelty, feasibility (industrial application), and technical added value (inventiveness).

We focused in particular on projects related to the various fields of mechanical engineering. $15 \%$ of the projects belonged to the aeronautics sector, $40 \%$ to the automotive sector, $25 \%$ to the energy sector and $20 \%$ to the mechanical and metallurgical manufacturing sector. 
The data collection procedure was diversified. Indeed, for academic projects, we closely followed the progress of these projects, and consulted the content of their deliverables (reports, definition drawings, applications and software... etc.), and we observed all their characteristics and the parameters that influence them. These projects generally take place as part of a final internship in an industrial company, under the supervision of a professor and an industrial manager, and last between 3 and 6 months.

Concerning extracurricular projects, we chose to study the innovative projects that were finalists in an international competition. We attended the oral presentations and demonstrations of these projects as a jury member. At the end of the competition, we conducted semi-directive interviews with the project leaders on more targeted issues in order to deepen our data collection.

\section{Study Results}

\subsection{Analysis of Semi-directive Interviews}

Before starting the interviews, we compiled a guide consisting of several questions, dedicated to the characterisation of the innovation training process.

We calculated the average recurrence rate of the elements corresponding to these analysis units in the responses of the various interviewees, respecting the following formula.

\section{Average $=\sum$ recurrence of the element $/$ total number of interviewees}

This recurrence is not necessarily verbal, but it is often thematic. The results are explained below.

In terms of the requirements expressed by the companies that are the customers of engineering schools producing skills we find the results in Table 3.

Table 3. Average responses to client requirements

\begin{tabular}{cc}
\hline Customer requirements & Average \\
\hline Investigation of the market & $70 \%$ \\
Creativity and inventiveness & $83 \%$ \\
Entrepreneurial behaviours & $2 \%$ \\
Technical skills & $100 \%$
\end{tabular}

Diverse Soft Skills: passion, openness, autonomy, adaptability, communication, audacity...etc. $\quad 100 \%$

We note that all companies require the acquisition of a combination of various technical and soft skills by the new engineers. Among these soft skills, we indirectly find those which are fundamental for the capacity to innovate such as autonomy, adaptability, communication, etc. We also note that creativity and inventiveness is required by $83 \%$ of interviewees. This shows the importance of innovation in industrial companies today, which reflects a great need to recruit human resources, in particular engineers having the appropriate skills and qualities to propose and develop innovative solutions. On the other hand, entrepreneurial behaviour, despite being a form of innovation, has the lowest rating (2\%), which is due to the fact that companies are looking to recruit loyal and reliable engineers who can carry out strategic long-term projects, whereas if such engineers have this capacity for business creation, they will quickly leave their jobs.

In terms of the objectives of graduation projects, company expectations are presented in Table 4.

Table 4. Average responses related to project expectations

\begin{tabular}{cc}
\hline Elements & Average \\
\hline Innovative solutions & $50 \%$ \\
Continuous improvement and updating of products and processes & $80 \%$ \\
Technical problem solving and equipment maintenance & $30 \%$ \\
\hline
\end{tabular}

Based on these results, we note that companies generally expect engineering students conducting graduation projects within their various departments to solve specific and real problems. Indeed, most projects are expected to propose solutions or readjustments, as part of the continuous improvement of different methods, procedures or processes, in order to optimise their productivity or the quality of their products. The proposal of innovative solutions is desired by half of the interlocutors, but it is not compulsory, because they know that there are constraints during the graduation 
projects that can prevent the realisation of these innovative solutions such as: lack of time and material resources, lack of experience of future engineers, fear of risk to the company... etc.

For cooperation between companies and engineering schools, the results are presented in Table 5.

Table 5. Average responses concerning cooperation between companies and engineering schools

\begin{tabular}{cc}
\hline Elements & Average \\
\hline Sponsoring and financing of innovative projects & $71 \%$ \\
Prizes in competitions and organisation of national competitions & $50 \%$ \\
Sponsoring events and other events organised by engineering students and teachers (sports days, business \\
representatives' forums, scientific and technical days, etc.) \\
Internship agreements & $100 \%$ \\
Incubators and intermediary associations & $83 \%$ \\
\hline
\end{tabular}

These results show that the main relationship between companies and engineering schools is the sponsorship of events organised within these institutions. This is justified by the economic implication of these events for these companies, in particular indirect advertising through the promotion of their logos, or the presence of a company representative. However, sponsorship and financing of innovative projects interest most of the stakeholders, this reflects the will of companies to integrate the world of innovation, and to support young people with innovative ideas.

Some industrialists have emphasised the criteria on which companies base their agreement to finance an innovative project, which can be summarised as: feasibility, the inventive technical aspect of the project, the added value for the ecosystem, the commercialisation and diffusion of its project.

\subsection{Analysis of Engineering Students' Projects}

The same analyses were conducted on the innovative projects of engineering students. In this case, the analysis units are the different parts of the innovation process from the point of view of the process approach. The results of the analysis are shown in Table 6 below.

Table 6. Average of the elements of the innovation process identified in the innovative projects of engineering students

\begin{tabular}{|c|c|c|}
\hline Elements of the process & Options & Average \\
\hline \multirow{8}{*}{ Financing } & Funding by industry & $90 \%$ \\
\hline & Funding by the university & $25 \%$ \\
\hline & Personal financing & $15 \%$ \\
\hline & $\begin{array}{l}\text { Financing from the income of the club's activities (sale of t-shirts, caps, key } \\
\text { rings, games and sports competitions (karting, paintball...)) }\end{array}$ & $25 \%$ \\
\hline & Prizes won in competitions & $20 \%$ \\
\hline & Purchase of new equipment & $75 \%$ \\
\hline & Recycling of products and machines from the school's workshops & $15 \%$ \\
\hline & $\begin{array}{l}\text { Recycling of products and old mechanical systems purchased outside the } \\
\text { school }\end{array}$ & $30 \%$ \\
\hline \multirow{5}{*}{ Equipment and material } & Equipment provided by partners & $55 \%$ \\
\hline & Use of ICT and CAD software (CATIA, AutoCAD, PATRAN,...) & $95 \%$ \\
\hline & Manufacturing of the product's components in the school's workshops & $56 \%$ \\
\hline & Manufacturing of the product's components outside the school's workshops & $44 \%$ \\
\hline & Use of project management tools & $55 \%$ \\
\hline \multirow[t]{2}{*}{ Management methods } & $\begin{array}{l}\text { Use of a problem-solving or continuous improvement approach (Functional } \\
\text { analysis, SADT...) }\end{array}$ & $45 \%$ \\
\hline & Use of innovation management tools (TRIZ, Bono hats...) & $5 \%$ \\
\hline
\end{tabular}




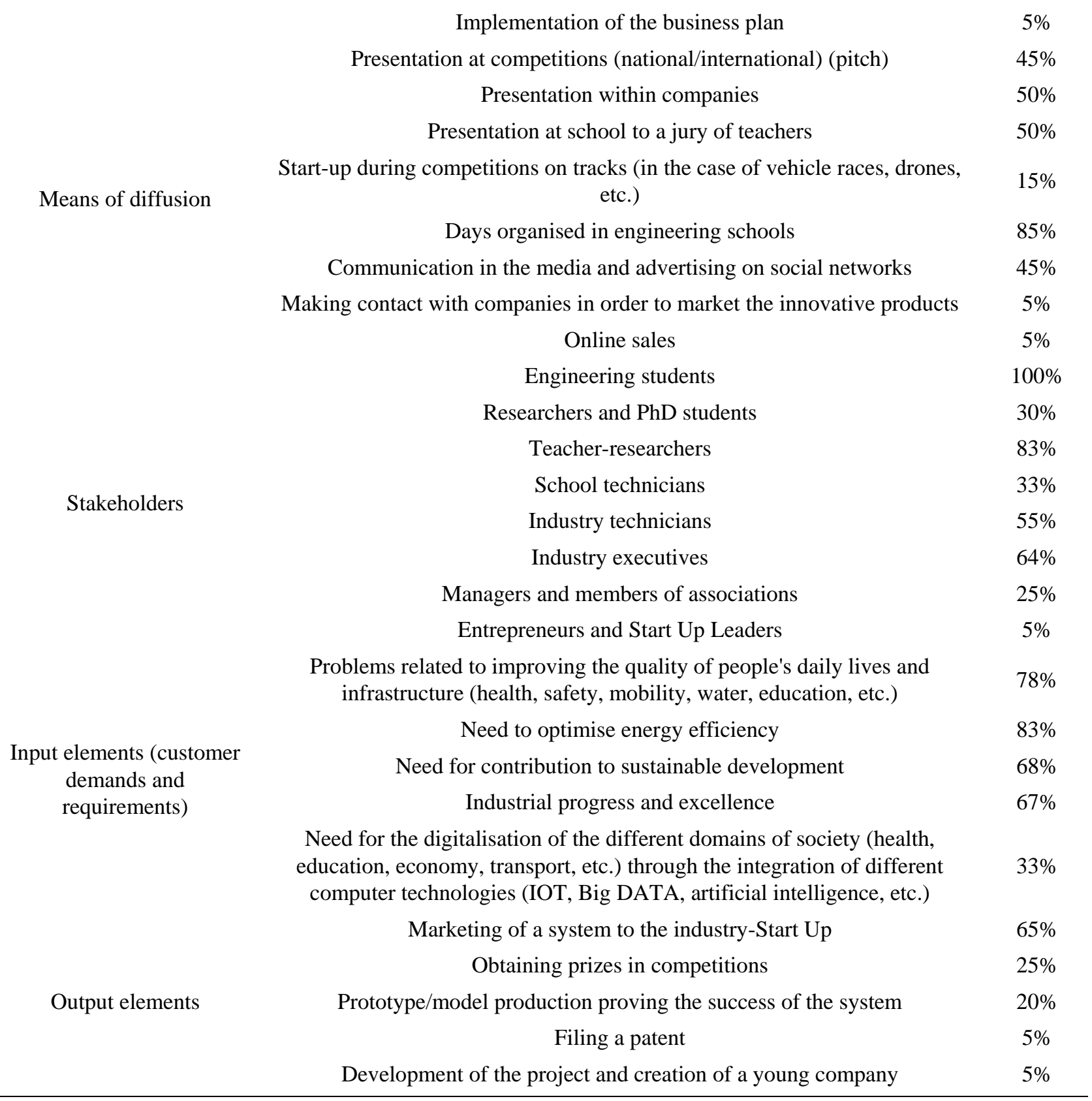

For the financing of projects, we note that the majority are financed by industrial companies that appreciated and approved the ideas of innovator students. There are other financial resources, but they are very limited such as funding allocated by the university, funding collected through club days... etc.

The equipment and material component includes all the material resources necessary for the implementation of the project. The objective of this analysis is to know what means are required and how to obtain them. Almost all projects are based on ICTs and design software in the upstream phases of the innovation process (creativity and development of the innovative solution) which are often available to engineering schools. For other equipment, the majority of projects require the purchase of new resources (raw materials, certain assembly techniques, etc.), while only $15 \%$ try to recycle old products existing in the school (metallic or composite materials, parts for internal combustion engines, etc.) because they do not meet their needs. For the space allocated to the project, $56 \%$ of the projects were carried out inside the school's workshops, where manufacturing and mechanical, electrical, thermodynamic control machines are located... etc. However, when some projects require the use of more advanced production processes, some project leaders use external service providers. 
According to the responses of the various innovative project leaders, almost half use traditional project management and problem-solving methods. However, the use of innovation and creativity engineering methods (TRIZ, Design thinking...) and the implementation of a business plan are almost absent. This is due to the lack of inclusion of courses on innovation management and their implementation in the curricula of mechanical engineering training.

Concerning the diffusion phase of the innovative solution, $85 \%$ of future engineers present their proposals during the scientific and technical days organised within engineering schools for extracurricular projects. For end-of-study projects, which represent half of our sample, they present the results of their projects within the company where the internship was carried out, and within their school. However, the diffusion of future engineers' innovations compared to existing market innovations is low, because they do not yet know how to create collaborative links with companies, or how to draw up plans for the commercialisation and marketing of their products. This comes back to their lack of experience, and their purely technical profile.

For any project, the interaction between experienced and diversified human resources is fundamental to its success. For the projects studied, the most active human resources in the innovation process are the engineering students who are the drivers of innovations, their academic teachers, and the managers within the companies that sponsor the projects. Other actors who should normally support and boost innovation, such as associations, entrepreneurs and start-ups leaders, are present in some projects but to a negligible extent.

This study of innovation projects also allowed us to know the inputs and outputs of the innovation process. The main inputs which represent the needs that innovative solutions must meet, are requirements related to the different challenges of sustainable development and the improvement in people's quality of life.

As for the outputs, the results of most projects are offered to companies to be created or marketed. However, we note that the rate of patent filings, or the creation of new companies, is very low. For patent filing, engineering students are sometimes unaware of the importance of intellectual property protection, or the invention does not meet the requirements for a patent. As for the future engineers, they do not follow the entrepreneurial path due to a lack of skill or assistance.

\section{Discussion and Design of the iInnovation Process Model}

We consider innovation training to be a process because it consists of a set of sequentially linked steps. The purpose of this process is to transform students into innovative engineers to ensure that the needs and requirements expressed by different organisations in the socio-economic world are met. Consequently, this approach, which is based on listening to the needs of the external environment and implementing measures to meet them, is similar to the quality approach. This approach is based on a set of principles, including the process approach.

The analysis of the various projects and interviews described above enabled us to design our innovation training process model for engineers through project pedagogy, based on the process approach. The results of this analysis are summarised in the form of the model developed from the preponderant averages of the various components studied. The components of the process are also supplemented by elements from the literature on innovation management.

\subsection{Macro-Process Model of Innovation Training}

The first step in modelling is the definition of the macro-process, through the identification of the general function of the model, the clients and their requirements, as well as the input and output elements. These elements are based on the analysis of interviews with manufacturers. Figure 1 shows the mapping of the macro-process model of innovation training.

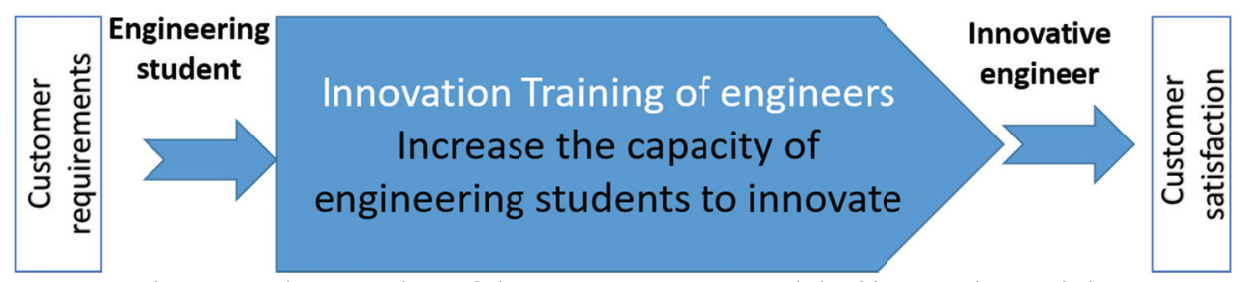

Figure 1. The mapping of the macro-process model of innovation training

The customers of the process that trains innovative and creative engineers, particularly in mechanical engineering, are the different types of companies (private and public, SMEs...etc.) that can recruit them. The latter express the 
need for engineers with technical and transversal skills to contribute to the improvement of their processes and products and to confront the challenges of globalisation such as increased competitiveness, technological dominance and market opening. On the other hand, the engineering profession can extend into the field of entrepreneurship through the creation of companies and in particular start-ups that try to meet the diverse needs of society. Thus, the clients of the macro-process of building innovative engineering profiles are not limited to the world of industrial organisations, but take on a broader scope that encompasses the entire socio-economic fabric. This refers to a sociotechnical approach to innovation that considers the latter to be a convergence of needs, knowledge, and multiple dimensions, which are part of the innovation ecosystem. Thus, an innovation can only have meaning if it meets a real need expressed not only by institutions but also by society. (Adam \& Coco, 2018)

In order to define our study, in this work we focused on a single component, which is the engineers' training in innovation through Project-Based Learning (PBL).

\subsection{Innovation Process Modelling}

The next step consists in modelling the innovation process. The purpose of this model represented in Figure 2 is to propose a structuring of the approach to the implementation and supervision of innovative projects that will promote the students' capacity to innovate.

It is important to mention that this model represents a nonlinear process, because there are interactions among the different components of the process, and the different phases of the process may not respect the order proposed in this model. That means that we can start a new phase without completing the last, or we can return to change some details in another past phase.

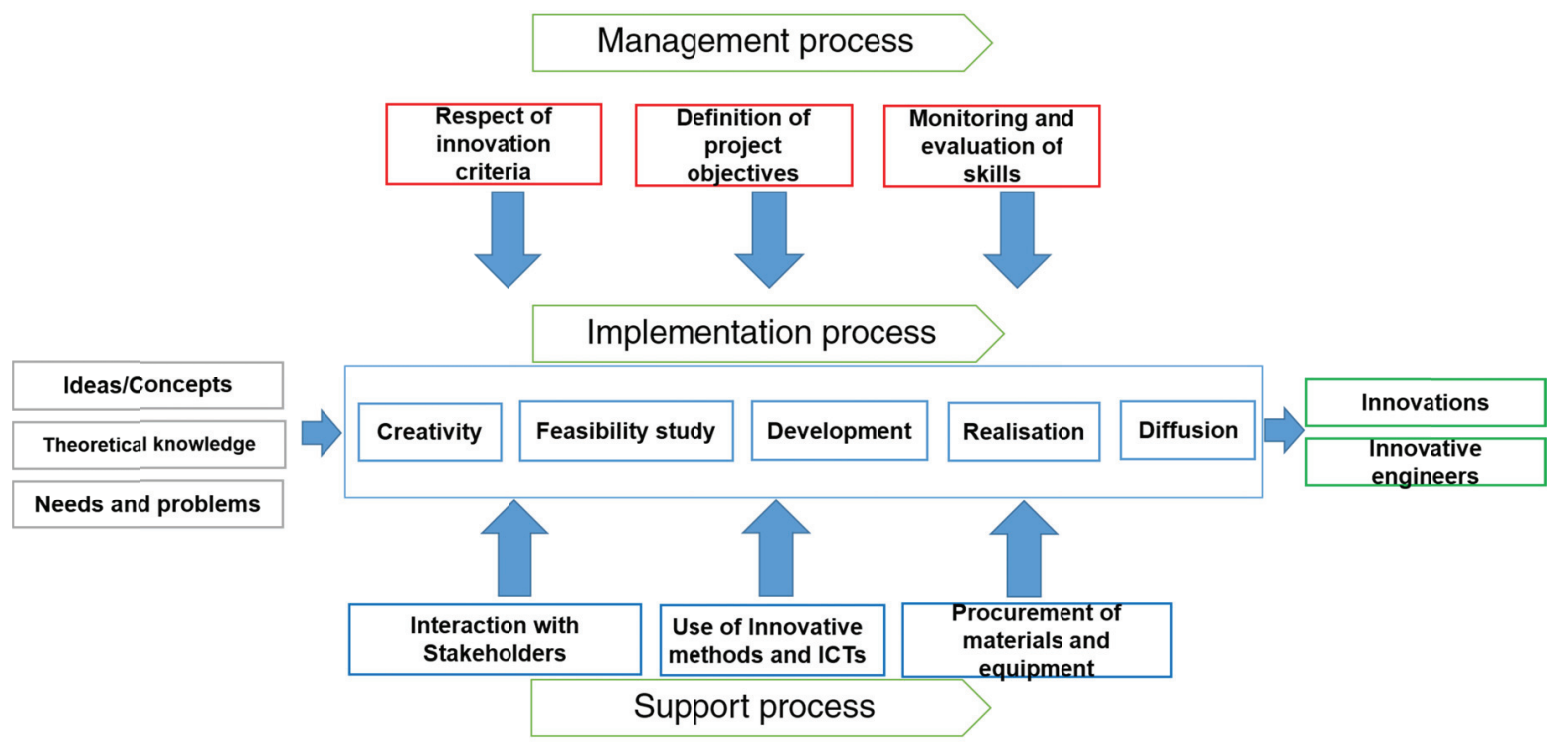

Figure 2. The proposed systemic model of the innovation process in students' projects

The proposed model in Figure 2 allowed us to identify steps and guidelines to be implemented when supervising projects carried out by engineering students so that they are innovative and creative

\subsubsection{Implementation Process}

The analysis of the projects studied allowed us to determine that engineering students do not follow a precise and structured innovation process in the form of standard steps. Indeed, in the case of academic projects, they generally follow traditional problem-solving methods or technical methodologies. This hypothesis has been confirmed in a previous work (Zergout, Ajana, Haddouchane, \& Bakkali, 2018a). As for extracurricular projects, students work in an intuitive way and engage directly in technical study. Therefore, we have based the steps of the process of carrying out innovative projects on the innovation process generally used within companies.

Through the state of the art synthesis, we selected the steps of the innovation process that are more general and global, and we modified their details according to the characteristics of our context. The aim of this operation is to propose an innovation process appropriate to our context which is the training of engineers. Indeed, engineer training institutions, unlike companies, are institutions with limited internal financial resources allocated to student activities. 
They must therefore seek external partners and funding. In addition, the main objective of the proposed process is innovation training, i.e. developing the various skills necessary for innovation through learning via a realistic and professional project. Therefore, steps focusing on theoretical training and evaluation are integrated into this process. Additional steps can be added to the main process that has been developed even in the innovation process in companies, such as feedback and continuous process improvement. These steps help to develop the notion of continuous innovation. In our case, feedback could enrich the courses and curriculum in engineering education as well as the teaching and learning methods used (Xu, Houssin, Caillaud, \& Gardoni, 2010).

\subsubsection{Process Inputs}

Concerning the main entry elements, we find the ideas and imagination that form a basis for invention and creation. These elements can be developed through courses, extracurricular activities or outside the training establishment by the observation of technology in the field or pursuing leisure activities... etc.

The problems and needs expressed by the various socio-economic domains, in particular the design and maintenance of infrastructures, the improvement of the quality of life of individuals, the contribution to the technological maturity of these different domains (industry, health, transport, etc.) represent inputs to the process. The sustainable development dimension is strongly present in most of the projects studied.

Before embarking on a project, the presence of certain basic technical and transversal skills is necessary. The latter are identified on the basis of the analysis of semi-directive interviews, in particular, the technical skills required for mechanical engineering (ability to design mechanical systems, define and meet specifications, analyse and calculate the characteristics of materials, etc.), and transversal skills required for project management.

\subsubsection{Process Outputs}

The results of the innovation process can take different forms. In the case where the project is well carried out and the material resources are sufficient, the output is an innovation that has been evaluated by experts and disseminated during competitions, scientific events or even marketed to companies. However, most of these projects take place during the training phase and are subject to certain constraints (lack of time and resources), which reduce the result of the process to detailed technical files or mock-ups proving the effectiveness of the design instead of finished products. Some projects use 3D printing technology.

The objective of this process is not limited to the production of innovations or patents, but extends to the construction of innovative profiles. Indeed, engineering students are actors in the innovation process, which allows them to develop new technical and transversal skills, by practising them in real situations and in different environments (companies, workshops, construction sites, laboratories...).

Finally, intellectual property management is necessary to protect the rights of innovation holders, through the filing of patents or the publication of scientific articles. However, few students are aware of this approach due to a lack of information and awareness.

\subsubsection{Support Processes}

In order to accomplish the various tasks related to the stages of the innovation process, a set of mechanisms and resources is needed. On the one hand, a diversity of human resources contributes to the success of the project. During the first phases, the role of the supervisors is to help the students to mobilise creative problem-solving methods and methods for generating innovative ideas from innovation engineering (TRIZ, Brainstorming, brain sketching, and design thinking...). For the technical development phases, researchers and doctoral candidates can contribute to the professionalisation of projects. For the rest of the phases, the intervention of people occupying different positions within the companies is requested, to help the students to implement the means and methods necessary for the concretisation of their designs (in particular the technicians working in the mechanical manufacturing workshops...).

The material needed to carry out the project depends largely on the budget allocated to the project and the equipment of the workshops and laboratories of the engineering schools. Indeed, the mechanical engineering department within engineering schools generally has workshops equipped with machines carrying out different mechanical manufacturing processes (machining, moulding, welding, etc.), testing machines to study the mechanical behaviour of systems, furnaces (for metals and composites), metrology tools, 3D printers, etc. However, these facilities vary from one school to another. When students cannot carry out their projects within their own school, they can resort to external services.

For raw materials and components of the designed product, they are usually ordered from a supplier offering reasonable prices, or recycled from old mechanical systems that are not operational but not worn. In this case, they 
can also contribute to the protection of the environment and thus to sustainable development. There are different sources of funding. However, according to the analysis of the projects studied, the implementation and dissemination of innovative projects are based on two main methods of financing: corporate sponsorship or prizes obtained during national and international competitions.

It is undeniable that a project cannot demonstrate professionalism and rigour without the deployment of methods and tools that ensure its consistency and technicality. During the first phases of generating and selecting innovative ideas, students can rely on technological observation through scientific and reliable databases. For the technical development phase, multiple software packages can be used such as: computer-aided design, simulation and mechanical structure calculation software (CATIA, AutoCAD...etc.).Table 7 synthetizes the main support elements of our innovation process and associates them to each step of the realisation process.

Table 7. The components of the implementation and support process of innovative mechanical engineering projects

\begin{tabular}{|c|c|c|c|c|}
\hline \multirow{2}{*}{\multicolumn{2}{|c|}{$\begin{array}{c}\text { Stages of the implementation } \\
\text { process }\end{array}$}} & \multicolumn{3}{|c|}{ Elements of the support process } \\
\hline & & Means & Methods & Actors \\
\hline \multirow{3}{*}{ Creativity } & $\begin{array}{l}\text { Define and } \\
\text { analyse a } \\
\text { problem }\end{array}$ & $\begin{array}{l}\text { Control charts, metrology } \\
\text { tools, questionnaires, } \\
\text { calculation and statistics } \\
\text { software,...etc. }\end{array}$ & $\begin{array}{l}\text { Active observation, } \\
\text { experimental design, } \\
\text { statistical control of } \\
\text { processes,...etc. }\end{array}$ & $\begin{array}{l}\text { Any person } \\
\text { concerned by } \\
\text { the problem, } \\
\text { supervisors }\end{array}$ \\
\hline & $\begin{array}{l}\text { Generate } \\
\text { creative } \\
\text { ideas }\end{array}$ & $\begin{array}{l}\text { Internet, scientific } \\
\text { databases, sites covering } \\
\text { technology,...etc. }\end{array}$ & $\begin{array}{l}\text { Technology observation, } \\
\text { brainstorming, innovation } \\
\text { management tools...etc. }\end{array}$ & $\begin{array}{l}\text { Supervisors, } \\
\text { PhD students }\end{array}$ \\
\hline & $\begin{array}{l}\text { Evaluate and } \\
\text { choose a } \\
\text { solution }\end{array}$ & Calculation software,...etc. & $\begin{array}{l}\text { Decision-making methods, } \\
\text { benchmarking,...etc. }\end{array}$ & $\begin{array}{l}\text { Supervisors, } \\
\text { PhD students }\end{array}$ \\
\hline \multirow{3}{*}{$\begin{array}{l}\text { Feasibility } \\
\text { study }\end{array}$} & $\begin{array}{l}\text { Listening to } \\
\text { the needs of } \\
\text { different } \\
\text { stakeholders }\end{array}$ & $\begin{array}{l}\text { Questionnaire, social } \\
\text { networks, applications for } \\
\text { studying audiences and } \\
\text { market news,...etc. }\end{array}$ & $\begin{array}{l}\text { Market research, customer } \\
\text { orientation, design } \\
\text { thinking,...etc. }\end{array}$ & $\begin{array}{c}\text { Project clients, } \\
\text { supervisors, } \\
\text { engineers }\end{array}$ \\
\hline & $\begin{array}{l}\text { Study of the } \\
\text { technical } \\
\text { and financial } \\
\text { feasibility }\end{array}$ & $\begin{array}{l}\text { Project management } \\
\text { software (MS Project), } \\
\text { calculation software } \\
\text { (Excel),...etc. }\end{array}$ & $\begin{array}{l}\text { Project management, } \\
\text { finance, risk management }\end{array}$ & $\begin{array}{l}\text { Engineers, } \\
\text { supervisors, } \\
\text { accountants }\end{array}$ \\
\hline & $\begin{array}{l}\text { Define the } \\
\text { business } \\
\text { plan }\end{array}$ & Project portfolio & $\begin{array}{l}\text { Innovation management } \\
\text { tools }\end{array}$ & $\begin{array}{l}\text { Engineers } \\
\text { (project } \\
\text { managers or } \\
\text { contractors) }\end{array}$ \\
\hline \multirow{3}{*}{ Development } & $\begin{array}{l}\text { Define the } \\
\text { functional } \\
\text { specification } \\
\text { s }\end{array}$ & Standard NF X 50-100 & $\begin{array}{c}\text { Functional analysis, Value } \\
\text { analysis...etc. }\end{array}$ & $\begin{array}{l}\text { Supervisors, } \\
\text { engineers, } \mathrm{PhD} \\
\text { students }\end{array}$ \\
\hline & $\begin{array}{l}\text { Design and } \\
\text { dimension }\end{array}$ & $\begin{array}{l}\text { Computer-aided design and } \\
\text { drawing and mechanical } \\
\text { calculation software } \\
\text { (CATIA, ABAQUS, } \\
\text { AutoCAD...etc.) }\end{array}$ & $\begin{array}{l}\text { Calculation of structures, } \\
\text { studying material's } \\
\text { behaviour, Sizing, design } \\
\text { and technical drawing, } \\
\text { eco-design, choosing } \\
\text { material, modelling...etc. }\end{array}$ & $\begin{array}{l}\text { PhD students, } \\
\text { R\&D } \\
\text { engineers, } \\
\text { supervisors }\end{array}$ \\
\hline & $\begin{array}{l}\text { Test and } \\
\text { validate } \\
\text { (make a } \\
\text { prototype) }\end{array}$ & $\begin{array}{l}\text { Manufacturing machines, } \\
\text { 3D printer, Metrology } \\
\text { tools, three-dimensional } \\
\text { metrology machine, } \\
\text { computer-aided design and }\end{array}$ & $\begin{array}{l}\text { Mechanical engineering } \\
\text { techniques, manufacturing } \\
\text { process of materials...etc. }\end{array}$ & $\begin{array}{l}\text { Technicians, } \\
\text { supervisors, } \\
\text { mechanical } \\
\text { production } \\
\text { engineers, }\end{array}$ \\
\hline
\end{tabular}




\begin{tabular}{|c|c|c|c|}
\hline & $\begin{array}{l}\text { manufacturing software, } \\
\text { mechanical testing and } \\
\text { non-destructive testing } \\
\text { machines, raw material, } \\
\text { miscellaneous equipment }\end{array}$ & & ...etc. \\
\hline $\begin{array}{l}\text { Search for } \\
\text { ways and } \\
\text { means }\end{array}$ & $\begin{array}{l}\text { Quotation, sponsorship } \\
\text { file, contact database }\end{array}$ & $\begin{array}{c}\text { Negotiation and } \\
\text { communication skills, } \\
\text { marketing }\end{array}$ & $\begin{array}{l}\text { Customers, } \\
\text { sponsors }\end{array}$ \\
\hline $\begin{array}{l}\text { Realise and } \\
\text { implement }\end{array}$ & $\begin{array}{l}\text { Manufacturing machines, } \\
\text { 3D printers, Metrology } \\
\text { tools, three-dimensional } \\
\text { metrology machines, } \\
\text { computer-aided design and } \\
\text { manufacturing software, } \\
\text { mechanical testing and } \\
\text { non-destructive testing } \\
\text { machines, raw material, } \\
\text { miscellaneous equipment }\end{array}$ & $\begin{array}{l}\text { Mechanical engineering } \\
\text { techniques, manufacturing } \\
\text { process of materials...etc. }\end{array}$ & $\begin{array}{l}\text { Technicians, } \\
\text { supervisors, } \\
\text { mechanical } \\
\text { production } \\
\text { engineers, } \\
\text {...etc. }\end{array}$ \\
\hline Evaluate & $\begin{array}{c}\text { PPT, prototype, } \\
\text { implementation results.... }\end{array}$ & Evaluation criteria & $\begin{array}{c}\text { Professors and } \\
\text { industrialists }\end{array}$ \\
\hline Diffuse & $\begin{array}{l}\text { Poster, Packaging, Social } \\
\text { Networks }\end{array}$ & Marketing & Customers \\
\hline
\end{tabular}

\subsubsection{Management Process}

The main objective of this part of the model is to supervise the achievement of the objectives expected by the project and to ensure consistency between the different components. Thus, during the creativity and idea generation stages, care must be taken to ensure that the innovation criteria mentioned in the previous section are met. It is also important to establish specifications that explain the objectives of the project and its aims before the start of the development phase. As the project progresses, a dashboard is set up to visualise the variation in indicators that help in the evaluation of projects. The professor (or industrialist) supervising the project can choose indicators quantifying the technical and transversal skills that boost innovation capacity. The end of the process must complete the project through a global evaluation of the process and its impact on the acquisition of the skills and knowledge necessary for innovation by the engineering student. These elements could represent feedback on the experience contributing to the continuous improvement of this process and engineering innovation training in general.

\section{Some Feedback from Experience}

The model of the process of carrying out an innovative project has been proposed within the Mechanical Engineering Department at the "Higher National School of Electricity and Mechanics" (ENSEM) in Casablanca, but it is not yet considered as an independent module. We first applied it to end-of-study projects carried out by third-year mechanical engineering students in 2016 and 2017. It has also been applied as a complement to an environmental management course, to propose innovative solutions that can help protect the environment. The results of these experiments have been published (Zergout, Ajana, Haddouchane, \& Bakkali, 2018b). The students had to divide into groups of three, and work on issues related to: the overconsumption of water and electrical energy, waste and scrap management in mechanical manufacturing workshops, the deterioration of green spaces, paper use and management... etc. Each group was asked to develop an innovative solution by following the steps of the proposed process.

This study highlighted the relevance of systemic modelling in understanding and organising the innovation process in engineering education. The limitations of this study lie in the lack of time and resources available to students for the implementation of the project, which prevented them from reaching the last phase of the process, which is the implementation and dissemination of innovation.

\section{Conclusion}

The interest in this study lies in the description of the approach used to design a model of the innovation training process through project-based learning. This proposal is the result of the analysis of a diversified data set from multiple case studies in the field of mechanical engineering education. On the one hand, we conducted semi-directive 
interviews with industrialists in order to determine the requirements of the socio-economic world and the main function of the process. On the other hand, we have described the details of innovative projects carried out by engineering students from various fields (automotive, aeronautics, etc.). The objective is to determine the elements and stages of the implementation, support and management processes that constitute our model.

The contribution of this work is to underline the importance of process-based modelling, which can be considered as a systemic approach, to understanding the complexity of the innovation training problem. This model invites us to develop an interdisciplinary approach through which the theoretical notions called for derive from complementary and interdependent scientific disciplines (engineering sciences, management sciences and educational sciences). As a perspective, we aim to apply the proposed model to a set of projects carried out in other ENSEM departments (electrical, industrial and computer engineering), and even in other engineering schools in other countries such as ENSTA Bretagne in France and ENIS in Tunisia. We are conducting research with these schools as part of a Franco-Maghreb project on the issue of innovation among engineers. The evaluation of the results obtained will ensure the continuous improvement of our model.

\section{References}

Adam, C., \& Coco, S. (2018). Développement de dispositifs de formation des ingénieurs à l'innovation: vers l'éco-innovation. In D. Lemaître (Dir), (Formation des ingénieurs à l'innovation), (pp. 237-252). Iste editions.

AMIC. (2014). (Association Marocaine des investisseurs en capital). (Etat des lieux sur le financement de l'Innovation au Maroc), Grant Thornton conseil.

Bernstein, B., \& Singh, P. J. (2006). An integrated innovation process model based on practices of Australian biotechnology firms. Technovation, 26(5-6), 561-572. https://doi.org/10.1016/j.technovation.2004.11.006

Besançon, M., Lubart, T., \& Barbot, B. (2013). Creative Giftedness and Educational Opportunities. Educational and Child Psychology, 30(2), 79-88. https://hal-univ-paris10.archives-ouvertes.fr/hal-01392541/

Blondel, D. (2002). Le rôle des scientifiques dans le processus d'innovation. Alter N., Les logiques de l'innovation: approche pluridisciplinaire, $\quad$ Paris: la https://www.cairn.info/les-logiques-de-1-innovation--9782707136954-page-129.htm

Bourgeois-Bougrine, S., Buisine, S., Vandendriessche, C., Glaveanu, V., \& Lubart, T. (2017). Engineering students' use of creativity and development tools in conceptual product design: What, when and how?. Thinking Skills and Creativity, 24, 104-117. https://doi.org/10.1016/j.tsc.2017.02.016

Brandenburg, H., \& Wojtyna, J. P. (2006). L'approche processus, mode d'emploi. Editions Eyrolles.

Christofol, H., Corsi, P., Crubleau, P., Delamarre, A., \& Samier, H. (2011). Modélisation des processus d'innovation en PME. Congrès International de Génie Industriel. Retrieved from https://sam.ensam.eu/handle/10985/6719

Cooper, R. G. (1990). Stage-gate systems: a new tool for managing new products. Business horizons, 33(3), 44-54. https://doi.org/10.1016/0007-6813(90)90040-I.

Ferguson, D. M., Jablokow, K. W., Ohland, M. W., \& Purzer, Ş. (2017). Identifying the Characteristics of Engineering Innovativeness. Engineering Studies, 9(1), 45-73. https://doi.org/10.1080/19378629.2017.1312419

Ferone, E., Pietroni, D., Petroccia, S., \& Antonio Alberto, A. (2018). Organizational innovation: a systemic approach. International Review of Sociology, 28(3), 419-431. https://doi.org/10.1080/03906701.2018.1529072

Forest, J., Chouteau, M., \& Nguyen, C. (2011). Conceptions de l'innovation et formations de l'ingénieur. https://halshs.archives-ouvertes.fr/halshs-00631385/

Gil, E.C., Gardelle L., \& Tabas, B. (2018). De l'innovation technologique à l'innovation «située» : pour une meilleure adaptation des formations d'ingénieurs aux défis sociétaux du XXIe siècle. In D. Lemaître (Dir), (Formation des ingénieurs à l'innovation), (pp.19-34). Iste editions.

Gómez-Pablos, V. B., del Pozo, M. M., \& Muñoz-Repiso, A. G. V. (2017). Project-based learning (PBL) through the incorporation of digital technologies: An evaluation based on the experience of serving teachers. Computers in Human Behavior, 68, 501-512. https://doi.org/10.1016/j.chb.2016.11.056

Kojmane, J., \& Aboutajeddine, A. (2015). Enjoyeering Senior: Un projet de conception et développement de produits innovants pour les élèves-ingénieurs. https://hal.archives-ouvertes.fr/hal-01260774/

Kövesi, K., \& Csizmadia, P. (2018). Compétences et capacités des innovateurs: nouvelles priorités et nouvelles exigences pour les diplômés en ingénierie. In D. Lemaître (Dir), (Formation des ingénieurs à l'innovation), 
(pp.75-98). Iste editions.

Norme NF EN ISO 9001:2015 (2015).Système de management de la qualité. Edition Afnor, https://www.iso.org/fr/standard/62085.html.

OMPIC (2014). Guide sur le brevet d'invention. http://www.ompic.org.ma/sites/default/files/field/Guide\%20sur\%20les\%20brevets\%20d\%27invention.pdf

Penide, T., Gourc, D., Pingaud, H., \& Peillon, P. (2013). Innovative process engineering: a generic model of the innovation process.International Journal of Computer Integrated Manufacturing, 26(3), 183-200. https://doi.org/10.1080/0951192X.2012.717715

Proulx, J. (2004). L'apprentissage par projet. PUQ. https://doi.org/10.2307/j.ctv5j01fr

Silva, A., Leite, M., Vilas-Boas, J., \& Simões, R. (2019). How education background affects design outcome: teaching product development to mechanical engineers, industrial designers and managers. European Journal of Engineering Education, 44(4), 545-569. https://doi.org/10.1080/03043797.2018.1465029

Soares, F. O., Sepúlveda, M. J., Monteiro, S., Lima, R. M., \& Dinis-Carvalho, J. (2013). An integrated project of entrepreneurship and innovation in engineering education. Mechatronics, 23(8), 987-996. https://doi.org/10.1016/j.mechatronics.2012.08.005

Widyaningsih, S. W., \& Yusuf, I. (2020). Implementation of Project-Based Learning (PjBL) Assisted by E-Learning through Lesson Study Activities to Improve the Quality of Learning in Physics Learning Planning Courses. International Journal of Higher Education, 9(1). https://doi.org/10.5430/ijhe.v9n1p60

Xu, J., Houssin, R., Caillaud, E., \& Gardoni, M. (2010). Macro process of knowledge management for continuous innovation. Journal of knowledge management, 14(4), 573-591. https://doi.org/10.1108/13673271011059536

Yin, R. (2003). K. (2003). Case study research: Design and methods. Sage Publications, Inc, 5, 11.

Zergout, I., Ajana, S., Haddouchane, Z. A., \& Bakkali, S. (2018a). Assessing the innovation process in mechanical engineering projects. International Journal of Innovation and Applied Studies, 23(4), 647-660. Retrieved from http://www.ijias.issr-journals.org/abstract.php?article=IJIAS-18-203-30

Zergout, I., Ajana, S., Haddouchane, Z. A., \& Bakkali, S. (2018b). Modeling test of the process of realization of innovative projects in an engineering school in Morocco. International Journal of Innovation and Scientific Research, 40(1), 88-97. Retrieved from http://www.ijisr.issr-journals.org/abstract.php?article=IJISR-18-239-04 